\title{
PENGARUH PENDEKATAN PENDIDIKAN MATEMATIKA REALISTIK INDONESIA TERHADAP KEMAMPUAN PEMECAHAN MASALAH MATEMATIS BERDASARKAN ADVERSITY QUOTIENT
}

\author{
Rika Melyanti ${ }^{\mathrm{a}}$, Rohana $^{\mathrm{b}}$, Ali Syahbana ${ }^{\mathrm{c}}$ \\ Program Studi Pendidikan Matematika FKIP UPGRI Palembang \\ Jl. Jend A. Yani, Plaju Palembang \\ arikamelyanti19@gmail.com, brohana_pgri@yahoo.com, ${ }^{\mathrm{c}} \mathrm{syahbanaumb} @$ yahoo.com
}

\begin{abstract}
ABSTRAK
Penelitian ini bertujuan untuk mengetahui ada atau tidak ada pengaruh pendekatan PMRI terhadap kemampuan pemecahan masalah matematis berdasarkan Adversity Quotient (AQ) siswa secara keseluruhan maupun masing-masing level AQ serta ada atau tidak ada interaksi antara pendekatan pembelajaran (PMRI dan konvensional) dengan AQ (Quitters, Campers, Climbers) terhadap kemampuan pemecahan masalah matematis siswa. Penelitian ini merupakan penelitian eksperimen dengan factorial design. Populasi penelitian ini adalah siswa kelas VIII SMP Negeri 1 Talang Kelapa Tahun Ajaran 2017/2018. Sampel dalam penelitian ini adalah siswa kelas VIII.4 (Kelas eksperimen) dan siswa kelas VIII.1 (Kelas kontrol) yang ditentukan secara acak. Pengumpulan data menggunakan tes dan angket. Data dianalisis menggunakan uji Independent Samples Test, uji Mann Whitney-U dan analisis deskriptif. Hasil yang didapat menunjukkan: 1) ada pengaruh yang signifikan pendekatan PMRI terhadap kemampuan pemecahan masalah matematis berdasarkan AQ siswa secara keseluruhan; 2) ada pengaruh yang signifikan pendekatan PMRI terhadap kemampuan pemecahan masalah matematis berdasarkan level AQ (Campers, Climbers) siswa. Namun, tidak ada pengaruh yang signifikan pendekatan PMRI terhadap kemampuan pemecahan masalah matematis berdasarkan level AQ Quitters siswa; dan 3) tidak ada interaksi antara pendekatan pembelajaran (PMRI dan konvensional) dengan AQ (Quitters, Campers, Climbers) terhadap kemampuan pemecahan masalah matematis siswa.
\end{abstract}

Kata Kunci: Pendekatan PMRI, Kemampuan Pemecahan Masalah, Adversity Quotient

\begin{abstract}
This study aims to determine the presence or the absence of the influence of PMRI approach on mathematical problem solving ability based on Adversity Quotient (AQ) of students as a whole or at each level of AQ and whether or not the interaction is available between learning approach (PMRI and conventional) and AQ (Quitters, Campers, Climbers) with students' mathematical problem solving skills. This research is an experimental research with factorial design. The population in this study is the students of class VIII SMP Negeri 1 Talang Kelapa, Academic Year 2017/2018. Sample in this study is the students of class VIII.4 (experimental class) and students of class VIII.1 (Control class) who are randomly assigned. Data collection uses tests and questionnaires. Data is analysed using Independent Samples Test, Mann Whitney-U test and descriptive analysis. The results show: 1) there is a significant effect of PMRI approach on mathematical problem solving ability based on student AQ as a whole; 2) there is a significant effect of PMRI approach on mathematical problem solving ability based on student AQ level (Campers, Climbers). However, there is no significant effect of the PMRI approach on mathematical problem solving abilities based on students' AQ Quitters levels; and 3) there is no interaction between learning approaches (PMRI and conventional) and AQ (Quitters, Campers, Climbers) with students' mathematical problem solving abilities.
\end{abstract}

Keywords: PMRI Approach, Problem Solving Ability, Adversity Quotient

AdMathEdu | Vol.8 No.1 | Juni $2018 \quad$ Pengaruh... (Rika) 


\section{Pendahuluan}

Matematika sebagai cabang ilmu pengetahuan yang memegang peranan penting dalam kehidupan manusia. Menurut Yosheva (2013:13) bahwa matematika merupakan mata pelajaran yang dianggap sulit dipahami oleh siswa, dan sebagian siswa pun merasa takut bahkan tidak menyukai pelajaran matematika. Siswa yang mengalami kesulitan dalam menerima materi, maka akan sulit juga dalam menyelesaikan permasalahan matematika.

Menurut Hadi (2017:6), rendahnya prestasi siswa dalam matematika dapat dilihat dari Olimpiade Matematika Internasional yang setiap tahun diikuti siswa, hanya sedikit yang mendapat medali. Krisiandi (2016:11) menunjukkan bahwa data dari hasil TIMSS (Trends in International Mathematics and Science Study) pada tahun 2015 untuk bidang studi matematika yang diikuti siswa kelas IV SD dengan skor matematika 397, menempatkan Indonesia di nomor 45 dari 50 negara. Hal ini menunjukkan bahwa kemampuan siswa dalam bidang matematika masih sangat rendah.

Kemudian, berdasarkan hasil dari studi pendahuluan di kelas VIII SMP Negeri 1 Talang Kelapa pada tanggal 24 Mei 2017, bahwa nilai tertinggi yang diperoleh siswa dalam menjawab soal matematika adalah 61. Dari hasil tes soal tersebut juga, terlihat masih banyaknya siswa yang mendapat nilai di bawah 50 yakni sekitar 75,76\% dari 33 siswa. Hal tersebut menunjukkan bahwa kemampuan pemecahan masalah matematis siswa memang masih rendah.

Kemampuan pemecahan masalah sangat penting dalam pembelajaran matematika, karena pada hakekatnya pembelajaran matematika merupakan cara untuk menyelesaikan masalah melalui penerapan konsep-konsep matematika. Mawaddah (2015:167) berpendapat bahwa cara penyelesaian masalah yang didapat oleh siswa merupakan hasil dari pengetahuan dan pengalaman yang dimiliki siswa terkait dengan masalah yang ingin dicari penyelesaiannya.

Oleh karena itu, diperlukan pembelajaran matematika yang tepat agar siswa dapat menyelesaikan persoalan matematika yang ada. Salah satu alternatif yang dapat digunakan dalam pembelajaran matematika yaitu dengan menggunakan pendekatan Pendidikan Matematika Realistik Indonesia (PMRI).

Pendidikan Matematika Realistik merupakan pembelajaran matematika dengan pendekatan kontekstual. Menurut Sarbiyono (2016:165) dengan mengajukan masalah kontekstual (contextual problem), siswa secara bertahap dibimbing untuk menguasai 
konsep matematika. Menurut Saharah (2016:180), pembelajaran dengan menggunakan pendekatan matematika realistik dirancang berawal dari pemecahan masalah yang ada di sekitar siswa dan berbasis pada pengetahuan yang telah dimiliki oleh siswa, sehingga diharapkan dapat meningkatkan pemahaman matematika siswa.

Melalui penelitiannya, Sarbiyono (2016:170) menunjukkan bahwa kemampuan pemecahan masalah matematika siswa yang memperoleh pembelajaran matematika realistik lebih tinggi dibandingkan kemampuan pemecahan masalah matematika siswa yang memperoleh pembelajaran dengan metode konvensional (ceramah).

Selain pendekatan pembelajaran, setiap siswa mempunyai tingkat dan tipe kecerdasan (kemampuan) yang berbedabeda, sehingga hal tersebut memiliki pengaruh terhadap proses belajar siswa. Salah satu tipe kemampuan yang mempengaruhi keberhasilan seseorang dalam melakukan suatu kegiatan adalah Adversity Quotient (AQ). Menurut Stoltz (2000:11), AQ merupakan kemampuan yang dibutuhkan untuk mencapai kesuksesan. Stoltz (2000:18-20), mengatakan bahwa dalam menghadapi masalah terdapat tiga tipe, yaitu: tipe quitters, tipe campers, dan tipe climbers.
Berdasarkan hasil observasi yang telah dilakukan di SMP Negeri 1 Talang Kelapa pada siswa kelas VIII terlihat bahwa siswa memiliki AQ yang rendah. Dikatakan demikian, karena pada saat pemberian lembar soal matematika, siswa sudah menyerah dan mengeluh tidak bisa mengerjakan soal tersebut.

Sedangkan melalui penelitiannya, Bahktiar (2015:1135) menyatakan bahwa siswa yang memiliki Adversity Quotient (AQ) tipe climbers dan AQ tipe campers mempunyai prestasi belajar matematika yang lebih baik daripada siswa yang memiliki AQ tipe quitters, dan siswa yang memiliki AQ tipe climbers mempunyai prestasi belajar matematika yang sama dengan siswa yang memiliki AQ tipe campers.

Berdasarkan latar belakang tersebut, tujuan dari penelitian ini adalah: (1) untuk mengetahui ada atau tidak ada pengaruh yang signifikan pendekatan PMRI terhadap kemampuan pemecahan masalah matematis berdasarkan AQ siswa secara keseluruhan; (2) untuk mengetahui ada atau tidak ada pengaruh yang signifikan pendekatan PMRI terhadap kemampuan pemecahan masalah matematis berdasarkan masing-masing level AQ (Quitters, Campers, Climbers) siswa; (3) untuk mengetahui ada atau tidak ada interaksi antara pendekatan 
pembelajaran (PMRI dan konvensional) dengan AQ (Quitters, Campers, Climbers) terhadap kemampuan pemecahan masalah matematis siswa.

\section{Metode Penelitian}

Penelitian ini merupakan penelitian eksperimen dengan metode factorial design. Menurut Sugiyono (2016:76), desain faktorial merupakan modifikasi dari design true experimental, yaitu dengan memperhatikan kemungkinan adanya variabel moderator yang mempengaruhi perlakuan (variabel independent) terhadap hasil (variabel dependent).

Populasi penelitian ini adalah siswa kelas VIII SMP Negeri 1 Talang Kelapa Kabupaten Banyuasin Sumatera Selatan Tahun Ajaran 2017/2018. Teknik pengambilan sampel dengan teknik cluster random sampling. Terpilih sampel sebanyak 70 siswa; 35 siswa kelas VIII.1 dan 35 siswa kelas VIII.4.

Pengumpulan data menggunakan soal tes kemampuan pemecahan masalah matematis dan angket AQ yang sudah divalidasi. Hasil tes siswa dihitung sesuai dengan indikator kemampuan pemecahan masalah matematis, dan hasil angket siswa dihitung sesuai dengan indikator AQ.
Data yang terkumpul diuji normalitas dan homogenitas terlebih dahulu, setelah memenuhi syarat normal dan homogen, lalu dianalisis. Teknik analisis data menggunakan uji Independent Samples Test, uji Mann Whitney-U dan uji ANOVA dua jalur.

\section{Hasil dan Pembahasan}

Data hasil penelitian ini ada dua macam, yaitu data skor tes untuk mengukur tingkat kemampuan pemecahan masalah matematis siswa dan data skor angket untuk mengukur tingkat Adversity Quotient (AQ) siswa. Analisis data AQ dilakukan setelah siswa mengisi data AQ saat tes evaluasi pada pertemuan terakhir. Pengelompokkan AQ terbagi menjadi tiga kelompok yaitu siswa kelompok AQ quitters, campers dan climbers.

Sebelumnya data AQ dihitung uji normalitas menggunakan SPSS 16.0 for windows. Kriteria pengujiannya yaitu jika probabilitas (sig.) > 0,05, maka $\mathrm{H}_{0}$ diterima berarti sampel berdistribusi normal sedangkan jika probabilitas (sig.) $\leq 0,05$, maka $\mathrm{H}_{0}$ ditolak berarti sampel berdistribusi tidak normal (Kadir, 2015:156). Ringkasan hasil uji normalitas data AQ disajikan pada Tabel 1 berikut ini. 
Tabel 1. Uji Normalitas Data AQ

\begin{tabular}{ccccccc}
\hline Kelompok AQ & Pembelajaran & n & K-S & Sig. & Ho $_{0}$ & Kesimpulan \\
\hline Quitters & PMRI & 2 & 0,260 & 0,000 & Ditolak & Tidak Normal \\
& PK & 3 & 0,253 & 0,000 & Ditolak & Tidak Normal \\
Campers & PMRI & 26 & 0,173 & 0,043 & Ditolak & Tidak Normal \\
& PK & 24 & 0,147 & 0,195 & Diterima & Normal \\
Climbers & PMRI & 7 & 0,160 & 0,200 & Diterima & Normal \\
& PK & 8 & 0,242 & 0,188 & Diterima & Normal \\
Keseluruhan & PMRI & 35 & 0,124 & 0,195 & Diterima & Normal \\
& PK & 35 & 0,121 & 0,200 & Diterima & Normal \\
\hline
\end{tabular}

Tabel 1 menunjukkan bahwa berdasarkan data AQ secara keseluruhan maupun kelompok AQ climbers untuk setiap pembelajaran (PMRI dan PK) menunjukkan sampel berasal dari populasi yang berdistribusi normal. Berdasarkan data kelompok AQ (quitters, campers) untuk setiap pembelajaran (PMRI dan PK) menunjukkan sampel berasal dari populasi yang tidak berdistribusi normal.
Setelah dilakukan uji normalitas data AQ, kemudian dilakukan uji homogenitasnya. Kriteria pengujiannya yaitu jika sig. > 0,05, maka $\mathrm{H}_{0}$ diterima berarti kelompok distribusi data homogen sedangkan jika sig. $\leq 0,05$, maka $\mathrm{H}_{0}$ ditolak berarti kelompok distribusi data tidak homogen (Kadir, 2015:170). Ringkasan hasil uji homogenitas data AQ disajikan pada Tabel 2 berikut ini.

Tabel 2. Uji Homogenitas Data AQ

\begin{tabular}{ccccccc}
\hline Kelompok AQ & Pembelajaran & n & L-S & Sig. & Ho $_{0}$ & Kesimpulan \\
\hline Climbers & PMRI & 7 & 3,608 & 0,080 & Diterima & Homogen \\
& PK & 8 & & & & \\
Keseluruhan & PMRI & 35 & 0,748 & 0.390 & Diterima & Homogen \\
& PK & 35 & & & & \\
\hline
\end{tabular}

Tabel 2 menunjukkan bahwa berdasarkan data AQ secara keseluruhan maupun kelompok AQ climbers untuk setiap pembelajaran (PMRI dan PK) menunjukkan bahwa sampel berasal dari populasi data homogen.

Selanjutnya untuk analisis data kemampuan pemecahan masalah matematis dilakukan setelah siswa mengisi jawaban tes kemampuan pemecahan masalah matematis pada pertemuan terakhir.
Sebelum dilakukan uji hipotesis terhadap data kemampuan pemecahan masalah matematis, terlebih dahulu dilakukan uji prasyarat terhadap data tersebut yaitu berupa uji normalitas dan uji homogenitas data kemampuan pemecahan masalah matematis (KPMM). Uji prasyarat tersebut dihitung dengan menggunakan SPSS 16.0 for windows. Ringkasan hasil uji normalitas datanya disajikan pada Tabel 3 berikut ini. 
Tabel 3. Uji Normalitas Data KPMM

\begin{tabular}{ccccccc}
\hline Kelompok AQ & Pembelajaran & n & K-S & Sig. & Ho $_{\mathbf{0}}$ & Kesimpulan \\
\hline Quitters & PMRI & 2 & 0,260 & 0,000 & Ditolak & Tidak Normal \\
& PK & 3 & 0,363 & 0,000 & Ditolak & Tidak Normal \\
Campers & PMRI & 26 & 0,087 & 0,200 & Diterima & Normal \\
& PK & 25 & 0,150 & 0,171 & Diterima & Normal \\
Climbers & PMRI & 7 & 0,350 & 0,010 & Ditolak & Tidak Normal \\
& PK & 8 & 0,210 & 0,200 & Diterima & Normal \\
Keseluruhan & PMRI & 35 & 0,111 & 0,200 & Diterima & Normal \\
& PK & 35 & 0,143 & 0,069 & Diterima & Normal \\
\hline
\end{tabular}

Tabel 3 menunjukkan bahwa berdasarkan data AQ secara keseluruhan maupun kelompok AQ campers terhadap kemampuan pemecahan masalah matematis untuk setiap pembelajaran (PMRI dan PK) menunjukkan sampel berasal dari populasi yang berdistribusi normal. Analisis statistik yang digunakan selanjutnya adalah statistik parametrik yaitu uji Independent Samples Test. Berdasarkan data kelompok AQ (quitters, climbers) terhadap kemampuan pemecahan masalah matematis untuk setiap pembelajaran (PMRI dan PK) menunjukkan bahwa sampel berasal dari populasi yang tidak berdistribusi normal. Sehingga analisis statistik yang digunakan selanjutnya adalah statistik non parametrik yaitu uji Mann Whitney- $U$.

Ringkasan hasil uji homogenitas data kemampuan pemecahan masalah matematis disajikan pada Tabel 4 berikut ini.

Tabel 4.Uji Homogenitas Data KPMM

\begin{tabular}{ccccccc}
\hline Kelompok AQ & Pembelajaran & n & L-S & Sig. & Ho $_{0}$ & Kesimpulan \\
\hline Campers & PMRI & 26 & 0,112 & 0,739 & Diterima & Homogen \\
& PK & 24 & & & & \\
Keseluruhan & PMRI & 35 & 0,071 & 0,790 & Diterima & Homogen \\
& PK & 35 & & & & \\
\hline
\end{tabular}

Tabel 4 menunjukkan bahwa berdasarkan data AQ secara keseluruhan maupun kelompok AQ campers terhadap kemampuan pemecahan masalah matematis untuk setiap pembelajaran (PMRI dan PK) menunjukkan bahwa sampel berasal dari populasi data homogen.
Selanjutnya dilakukan uji hipotesis yaitu dengan menggunakan uji Independent Samples Test, uji Mann Whitney- $U$ dan uji ANOVA dua jalur. Kriteria yang digunakan adalah $\mathrm{H}_{0}$ diterima jika nilai signifikansi lebih dari 0,05. Hasil uji Independent Samples Test disajikan dalam Tabel 5 berikut. 
Tabel 5. Uji Perbedaan Menggunakan Uji-t Data KPMM

\begin{tabular}{cccccc}
\hline Kelompok AQ & Pembelajaran & T & $\begin{array}{c}\text { Sig. (2- } \\
\text { tailed })\end{array}$ & Ho $_{0}$ & Kesimpulan \\
\hline Campers & PMRI & 5,125 & 0,000 & Ditolak & Ada Perbedaan \\
Keseluruhan & $\begin{array}{c}\text { PK } \\
\text { PMRI } \\
\text { PK }\end{array}$ & 3,866 & 0,000 & Ditolak & Ada Perbedaan \\
\hline
\end{tabular}

Dengan menggunakan uji Independent Samples Test seperti yang terlihat pada Tabel 5, nilai sig.(2-tailed) lebih kecil dari 0,05 sehingga $\mathrm{H}_{0}$ ditolak. Jika dilihat dari kelompok AQ keseluruhan dan AQ campers, berarti ada perbedaan yang signifikan pendekatan PMRI terhadap kemampuan pemecahan masalah matematis berdasarkan AQ siswa secara keseluruhan dan berdasarkan level AQ Campers siswa.

Dapat disimpulkan bahwa ada pengaruh yang signifikan pendekatan
PMRI terhadap kemampuan pemecahan masalah matematis berdasarkan AQ siswa secara keseluruhan. Untuk AQ campers dapat disimpulkan bahwa ada pengaruh yang signifikan pendekatan PMRI terhadap kemampuan pemecahan masalah matematis berdasarkan level AQ Campers siswa.

Selanjutnya uji hipotesis menggunakan uji Mann Whitney- $U$ yaitu pada data yang tidak berdistribusi normal. Hasil uji Mann Whitney- $U$ disajikan dalam Tabel 6 berikut.

Tabel 6. Uji Perbedaan Menggunakan Uji Mann Whitney-U Data KPMM

\begin{tabular}{|c|c|c|c|c|c|}
\hline $\begin{array}{c}\text { Kelompok } \\
\text { AQ }\end{array}$ & Pembelajaran & $\bar{Z}$ & $\begin{array}{l}\text { Asymp } \\
\text { Sig. (2- } \\
\text { tailed) }\end{array}$ & $\mathbf{H}_{\mathbf{0}}$ & Kesimpulan \\
\hline Quitters & $\begin{array}{c}\text { PMRI } \\
\text { PK }\end{array}$ & $-0,577$ & 0,564 & Diterima & Tidak Ada Perbedaan \\
\hline Climbers & $\begin{array}{c}\text { PMRI } \\
\text { PK }\end{array}$ & $-2,754$ & 0,006 & Ditolak & Ada Perbedaan \\
\hline
\end{tabular}

Dengan menggunakan Uji Mann Whitney- $U$ seperti yang terlihat pada Tabel 6, kelompok AQ quitters mempunyai nilai Asymp Sig. (2-tailed) lebih besar dari 0,05 , sehingga $\mathrm{H}_{0}$ diterima. Hal ini berarti tidak ada perbedaan yang signifikan pendekatan PMRI terhadap kemampuan pemecahan masalah matematis berdasarkan level AQ Quitters siswa. Jika dilihat dari kelompok AQ AdMathEdu | Vol.8 No.1 | Juni 2018 climbers, nilai Asymp Sig. (2-tailed) lebih kecil dari 0,05 , sehingga $\mathrm{H}_{0}$ ditolak. Hal ini berarti ada perbedaan yang signifikan pendekatan PMRI terhadap kemampuan pemecahan masalah matematis berdasarkan level AQ Climbers siswa.

Dapat disimpulkan bahwa untuk AQ Quitters yaitu tidak ada pengaruh yang signifikan pendekatan PMRI terhadap kemampuan pemecahan masalah Pengaruh... (Rika) 
matematis berdasarkan level AQ Quitters siswa, untuk AQ Climbers dapat disimpulkan bahwa ada pengaruh yang signifikan pendekatan PMRI terhadap kemampuan pemecahan masalah matematis berdasarkan level AQ Climbers siswa.

Untuk menguji hipotesis ketiga digunakan uji ANOVA dua jalur. Hasil uji normalitas disajikan pada Tabel 3. Data tersebut menunjukkan bahwa secara keseluruhan probabilitas (sig.) data interaksi antara pembelajaran dengan AQ (quitters, campers, climbers) terhadap kemampuan pemecahan masalah matematis kelas eksperimen (PMRI) dan kelas kontrol (PK) lebih besar dari 0,05, berarti hipotesis nol diterima. Artinya secara keseluruhan data interaksi antara pembelajaran dengan AQ (quitters, campers, climbers) terhadap kemampuan pemecahan masalah matematis kelas eksperimen dan kelas kontrol berdistribusi normal.

Ditinjau dari AQ quitters pembelajaran PMRI dan konvensional, nilai probabilitas (sig.) data interaksi antara pembelajaran dengan AQ quitters terhadap kemampuan pemecahan masalah matematis kelas eksperimen (PMRI) maupun kelas kontrol (PK) lebih kecil dari 0,05 , hal ini berarti hipotesis nol ditolak, sehingga data tersebut tidak berdistribusi normal. Karena terdapat data kemampuan pemecahan masalah yang tidak berdistribusi normal, maka pengujian dengan menggunakan ANOVA dua jalur tidak dapat dilaksanakan. Oleh sebab itu, analisis tentang interaksi antara pembelajaran dan AQ (quitters, campers, climbers) terhadap kemampuan pemecahan masalah matematis mesti dilakukan secara kualitatif dengan memanfaatkan Gambar 1 berikut ini:

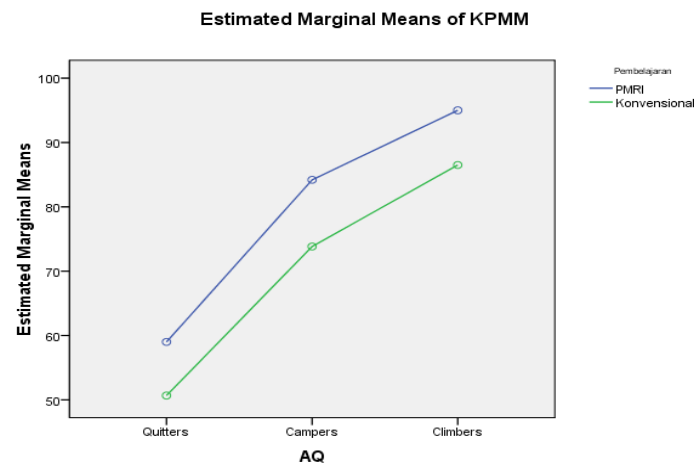

Gambar 1. Interaksi Antara Pendekatan PMRI dengan AQ (Quitters, Campers, Climbers) Terhadap KPMM 
Dari Gambar 1 di atas tampak bahwa siswa dengan AQ (quitters, campers, climbers) yang mendapat perlakuan pembelajaran PMRI jauh lebih tinggi dan lebih baik dibandingkan dengan yang mendapat pembelajaran konvensional. Di kelas eksperimen (PMRI), jika pencapaian kemampuan pemecahan masalah diurutkan dari terendah hingga terbesar maka urutannya adalah kemampuan pemecahan masalah matematis AQ quitters, campers, dan climbers. Di kelas kontrol (konvensional), jika pencapaian kemampuan pemecahan masalah diurutkan dari terendah hingga terbesar maka urutannya adalah kemampuan pemecahan masalah matematis AQ quitters, campers, dan climbers. Ada perbedaan urutan kemampuan pemecahan masalah matematis berdasarkan AQ antara kelas eksperimen (PMRI) dan kelas kontrol (konvensional). Oleh karena itu, tidak ada interaksi antara pembelajaran yang diberikan dan AQ siswa terhadap kemampuan pemecahan masalah matematis siswa dilihat dari AQ siswa quitters, campers dan climbers.

Berdasarkan hasil perhitungan yang telah dilakukan diperoleh bahwa ada pengaruh yang signifikan pendekatan PMRI terhadap kemampuan pemecahan masalah matematis berdasarkan AQ siswa secara keseluruhan. Hasil penelitian ini sejalan dengan penelitian yang dilakukan Wahidin dan Sugiman (2016), bahwa terdapat perbedaan pengaruh yang signifikan antara siswa yang mengikuti pembelajaran dengan pendekatan PMRI dibandingkan dengan siswa yang mengikuti pembelajaran secara konvensional ditinjau dari prestasi belajar, kemampuan pemecahan masalah, dan motivasi berprestasi.

Juga ada pengaruh yang signifikan pendekatan PMRI terhadap kemampuan pemecahan masalah matematis berdasarkan level AQ (Campers, Climbers) siswa. Namun, tidak ada pengaruh yang signifikan pendekatan PMRI terhadap kemampuan pemecahan masalah matematis berdasarkan level AQ Quitters siswa. Hasil ini sejalan dengan penelitian yang dilakukan Yosheva (2013), bahwa terdapat perbedaan kemampuan kognitif matematika kelompok siswa yang memiliki AQ Climbers yang pembelajarannya dengan menggunakan pendekatan RME bila dibandingkan dengan kelompok siswa yang memiliki AQ Climbers yang pembelajarannya dengan menggunakan pendekatan Konvensional. Tetapi tidak terdapat perbedaan kemampuan kognitif matematika kelompok siswa yang memiliki AQ (Campers, Quitters) yang 
pembelajarannya dengan menggunakan pendekatan RME dibandingkan dengan kelompok siswa yang memiliki AQ (Campers, Quitters) yang pembelajarannya dengan pendekatan konvensional. Selain itu hasil penelitian ini juga sejalan dengan hasil penelitian Ayuwanti (2015) yang menyimpulkan bahwa pada peserta didik dengan AQ quitters, model pembelajaran kooperatif tipe NHT, GI dan model pembelajaran langsung menghasilkan prestasi belajar matematika yang sama.

Terakhir, tidak ada interaksi antara pendekatan pembelajaran (PMRI dan konvensional) dengan AQ (Quitters, Campers, Climbers) terhadap kemampuan pemecahan masalah matematis siswa. Jika dilihat dari langkah-langkah pembelajaran, penyebab tidak adanya interaksi sebagai berikut: Pertama, pada saat pembelajaran dalam kelompoknya, tidak semua siswa menyampaikan suatu pertanyaan, artinya sedikit bertentangan dengan siswa aktif dan interaktif dalam pembelajaran PMRI. Hal ini disebabkan siswa belum tahu apa yang hendak ditanyakan. Kedua, ketika siswa dibimbing untuk menemukan permasalahan pada lembar kegiatan, jika kesadaran akan tujuan belajar kurang maka siswa tersebut tidak benar-benar mengikuti pembelajaran dengan baik.

\section{Kesimpulan}

Berdasarkan hasil analisis data penelitian, dapat dikemukakan beberapa kesimpulan sebagai berikut: (1) ada pengaruh yang signifikan pendekatan PMRI terhadap kemampuan pemecahan masalah matematis berdasarkan AQ siswa secara keseluruhan; (2) ada pengaruh yang signifikan pendekatan PMRI terhadap kemampuan pemecahan masalah matematis berdasarkan level AQ (Campers, Climbers) siswa. Namun, tidak ada pengaruh yang signifikan pendekatan PMRI terhadap kemampuan pemecahan masalah matematis berdasarkan level AQ Quitters siswa; (3) tidak ada interaksi antara pendekatan PMRI dengan AQ (Quitters, Campers, Climbers) terhadap kemampuan pemecahan masalah matematis siswa.

\section{Pustaka}

Ayuwanti, I., Tri A.K., \& Riyadi. 2015. Eksperimentasi

Model

Pembelajaran Kooperatif Tipe Numbered Heads Together (NHT) dan Group Investigation (GI) Pada Materi Segitiga dan Segiempat Ditinjau dari Adversity Quotient (AQ) SMP Negeri Se-Kabupaten Tulang Bawang Barat. Jurnal Elektronik Pembelajaran Matematika, 3(7) : 694-704. 
Bahktiar, H., Usodo, B., \& Riyadi. 2015. Eksperimentasi Model Pembelajaran Kooperatif Tipe Think Pair Share (TPS) dengan Problem Posing pada Pokok Bahasan Peluang Ditinjau dari Adversity Quotient (AQ) Siswa Kelas XI SMK di Kabupaten Boyolali Tahun Ajaran 2013/2014. Jurnal Elektronik Pembelajaran Matematika, 3(10) : 1127-1137.

Hadi, S. 2017. Pendidikan Matematika Realistik: Teori, Pengembangan, dan Implementasinya, Edisi Revisi. Jakarta: Rajawali Pers.

Kadir. 2015. Statistik Terapan Konsep: Contoh dan Analisis Data dengan Program SPSS/Lisrel dalam Penelitian. Jakarta: Rajawali Pers. Krisiandi. 2016, 15 Desember. Daya Imajinasi Siswa Lemah. Harian Kompas, Hal.11.

Mawaddah, S., \& Hana A. 2015. Kemampuan Pemecahan Masalah Matematis Siswa pada Pembelajaran Matematika dengan Menggunakan Model Pembelajaran Generatif (Generative Learning) di SMP. Jurnal EDU-MAT, 3(2) : 166-175.

Saharah, I.N.M., \& Baharuddin P. 2016. \begin{tabular}{lr} 
Penerapan & \multicolumn{2}{r}{ Pendekatan } \\
Matematika & Realistik Untuk
\end{tabular} AdMathEdu | Vol.8 No.1 | Juni 2018
Meningkatkan Hasil Belajar Siswa Kelas 1 SD Integral Rahmatullah Tolitoli pada Materi Penjumlahan dan Pengurangan Bilangan. Jurnal Kreatif Tadulako Online, 4(3) : 178-192.

Sarbiyono. 2016. Penerapan Pendekatan Matematika Realistik Terhadap Kemampuan Pemecahan Masalah Matematis Siswa. Jurnal Review Pembelajaran Matematika, 1(2) : 163-173Stoltz, Paul G. 2000. Adversity Quotient: Mengubah Hambatan Menjadi Peluang, (Terjemahan T. Hermaya). Jakarta: Grasindo.

Sugiyono. 2016. Metode Penelitian Kuantitatif, Kualitatif, dan $R \& D$. Bandung: Alfabeta.

Wahidin \& Sugiman. 2014. Pengaruh Pendekatan PMRI Terhadap Motivasi Berprestasi, Kemampuan Pemecahan Masalah, dan Prestasi Belajar. Jurnal Pythagoras, 9(1) : 99-109.

Yosheva, N., Kamid, \& Rusdi, M. 2013. Pengaruh Pendekatan RME dan AQ Terhadap Kemampuan Kognitif Matematika Siswa Kelas VII SMP. Tekno-Pedagogi, 3(1) : 12-27. 
